\title{
Knowledge Translation through Research-Based Theatre
}

\section{Lapplication des connaissances par le théâtre fondé sur la recherche}

\author{
by JOAN M. EAKIN, PHD \\ Professor, Department of Public Health Sciences \\ Faculty of Medicine, University of Toronto \\ Toronto, ON
}

MARION ENDICOTT

Injured Workers Consultants and the Bancroft Institute

Toronto, ON

\begin{abstract}
This case documents the metamorphosis of an academic public health project on the implementation of Ontario's return-to-work policies and practices into a community theatre project, the production of a play called Easy Money. The result was a highly successful knowledge translation initiative. Injured workers, the focus of the academic study, intensely identified with the play and were given hope that their individual experiences could be broadly translated. For the researchers, the undertaking provided new perspectives on the original research problem, validated their original findings and generated numerous topics for subsequent research.
\end{abstract}




\section{Résumé}

Ce cas décrit la transformation d'un projet universitaire en santé publique sur la mise en œuvre des politiques et pratiques de retour au travail de l'Ontario en un projet de théâtre communautaire et la production d'une pièce intitulée Easy Money. Le résultat a été une initiative très fructueuse d'application des connaissances. Les travailleurs blessés - le principal sujet de l'étude universitaire - se sont identifiés de très près à la pièce et celle-ci leur a donné l'espoir que leurs expériences individuelles pourraient être appliquées à grande échelle. Pour les chercheurs, l'initiative a fourni de nouvelles perspectives sur le problème de recherche initial; elle a validé leurs constatations et a généré de nombreux sujets pour des travaux de recherche futurs.

$\mathrm{J}$ oan Eakin, with research colleagues Ellen MacEachen and Judy Clarke from the Institute for Work and Health in Toronto, recently completed a study of a new system in Ontario for reducing disability from work-related injury and for getting injured workers back to work. The system features early return to work (before recovery), modified work (tasks adapted to the injury) and workplace self-reliance (primary self-administration by the workplace parties).

The study identified a number of problematic implications for small workplaces, including the harmful effects for injured workers and for social relationships in the workplace of what the researchers called a "discourse of abuse," the broadly experienced, institutionalized expectation that workers will misuse the compensation system.

Results of the research were published (Eakin et al. 2003; Eakin 2005) and presented to other researchers, administrators from the Ontario Workplace Safety and Insurance Board, policy makers, health practitioners and injured workers. The project resulted in a number of tangible outcomes, including change to Ontario's workplace injury reporting form, and invoked exceptional interest from the injured worker community. The success of these initial knowledge translation (KT) efforts prompted us to extend the reach of the study's findings in a novel way: using theatre.

\section{The KT Initiative}

The use of theatre as a medium of research communication and social change is increasingly recognized (McCall 2000). In Canada's health research arena, the very successful plays of Ross Gray and company (Gray and Sinding 2002) on the experience of cancer are probably unmatched in terms of reach and impact.

Inspired by these research-informed dramas, and in collaboration with the Injured Workers Consultants (a community legal clinic that had supported the study since its inception) and the Ontario Network of Injured Workers Groups, some funds were 
scrounged from other research grants to engage an experienced playwright-director, Kate Lushington. Under her guidance, we secured grants from the Ontario and Toronto arts councils and from several labour unions to fund the developmental stage of the project - a period of about one year, culminating in the first staging of the play Easy Money.

The purpose of the play is to communicate the research findings to injured workers, system administrators, policy makers, government legislators and the general public, and to involve injured workers themselves in the KT effort. The play was developed incrementally, starting with the writer-director's reading of the research report and extensive brainstorming sessions with the researcher and the production group about the key research ideas and how they might best be conveyed on stage.

The Injured Workers Theatre Collective - a group of injured workers - was formed through the client base of the legal clinic and met several times with the writer-director to relay personal stories and fuel the scriptwriting. A videographer recorded the storytelling and the participatory process with workers. Seven professional actors, ${ }^{1}$ a musician and design specialists were employed to stage the play.

The central motif of the play - a Kafkaesque game of snakes and ladders and the satirical portrayal of injury and compensation as "easy money" - emerged from the confluence of research findings, worker participation and artistic expression. The core analytic concepts and arguments of the research were given artistic expression through dialogue, music, song, movement and stage props.

\section{Results of the KT Experience}

The play was performed for the first time at the Toronto Mayworks Festival of the Arts in May 2005. Immediately following the show, a discussion was held with the audience (about 100 people, largely injured workers and their families) to harvest their feedback and ideas for improving the play. Not only were valuable suggestions made about the play, but input from the audience shed new light on aspects of the research analysis and generated new research topics. Planned follow-up activities include adapting the script for a broader audience (the general public, service providers and policy makers); producing videos; and sharing the script with other communities for local productions.

The production was hugely successful in terms of the immediate response of the audience. Injured workers identified intensely with the play's content. Many appeared to feel a sense of being understood for the first time. The use of theatre and professional actors seemed to elevate and legitimize their individual experiences and gave them hope that the institutional systems, in which many felt trapped and ill-served, could be made visible to the public. The response to the play was also validating to the researcher (supporting the "truth" value of the research) and to the community legal partners (as testimony to the effectiveness of their activism). 


\section{Lessons Learned}

Despite the evident success of the play, it is important to ask questions from the more abstract standpoint of KT.

First, what happens to scientific knowledge when it is transformed into art and into vehicles of advocacy and change? Is science enriched? Dumbed down? De-theorized? In our case, the play had the capacity both to convert abstract research into concrete form and to produce generalizable abstract knowledge from the empirical research findings (i.e., it picked up the generic, universal experience underlying individual stories). Thus, through the techniques of metaphor, dialogue and fiction, the characterization of experience in the play was personal and generic, individual and collective, particular and trans-situational.

A related issue stems from the observation that scientifically produced knowledge does not necessarily make "good" theatre or an effective tool for enlightenment or change. Would many people choose to attend a play that focused only on the grim hardships and

But can it do all of these without a conflict of interest and political purpose? And is theatre a better vehicle for some purposes than others? despair of injured workers? But what happens when research findings are altered for theatrical or communicative effect, or when research ideas that are too hard to stage are

left out? How does the introduction of humour and irony, for example, relate to the content of the original science? We will undoubtedly learn more about the relationship between science, art and political purpose as we turn to making the play speak to the different audiences of the general public, system administrators, service providers and policy makers.

Second, how should such KT endeavours be appraised, in terms of a return on investment? Whose benefits should be the pivot points of evaluation? In our case, the effectiveness of Easy Money as a form of KT could be assessed from multiple standpoints: as a salve and voice for injured workers, as a catalyst for reform among government legislators and administrators, as a source of public pressure for institutional change and as a source of guidance for future research. But can it do all of these without a conflict of interest and political purpose? And is theatre a better vehicle for some purposes than others?

Third, how significant are pragmatic rather than theoretical concerns in KT? Regardless of any abstract theory, its effective execution is deeply contingent upon 
practical, ground-level resources and considerations. For example, one practical barrier to KT activities can be inappropriate timing and availability of funding. In our case, a restrictive research grant funding policy led to the loss of unspent KT funds that could have been used for the start-up of Easy Money. Collaboration for creative activities such as this requires more flexible grant arrangements than are often available.

Another practical impediment to KT can be its low value as academic "capital." Such activities (particularly unorthodox undertakings such as Easy Money) may draw researchers into unfamiliar territory that requires time and energy to navigate (e.g., securing funding in the arts arena, learning how plays are mounted) and where the risks and outcomes are unknown. In addition, genuine collaboration can mean, for the researcher, a loss of "control" over the use and interpretation of intellectual property (quelle horreur in academia!).

\section{Conclusions and Implications}

The Easy Money experience underscores that KT, a quintessentially collaborative, cross-disciplinary exercise, can be effective only if there is something concrete in it for all partners. It cannot be induced by normative pressure alone (e.g., the belief that publicly funded research ought to be usable outside academia), nor even by practical necessity (e.g., KT as a requirement by research funding agencies).

In our case, for the community legal clinic collaborators, Easy Money aligned clearly with their organizational mission of improving the lives of injured workers and promoting legislative reform. For the participating injured workers, the play gave voice to personal experience and fostered a sense of meaning and community. For the artists, particularly the writer-director, Easy Money was an opportunity for political engagement and for a novel experience with community-based theatre. And for the researchers, the undertaking provided new perspectives on the original research problem and significant conceptual fodder for subsequent research. This confluence of interests appeared to be a major factor in making Easy Money a KT success story. How successful the play will be in this regard when it is brought to bear on audiences who have different stakes in the messages and who may not really want to hear them, is a story for a future KT casebook.

Correspondence may be directed to: Joan M. Eakin, Professor, Department of Public Health Sciences, Faculty of Medicine, University of Toronto, Health Sciences Building, 155 College Street, 6th Floor, Toronto, Ontario, Canada M5T 3M7. Tel: 416-978-8502. Fax: 416-978-2087. Email: joan.eakin@utoronto.ca.

Joan Eakin's study for this paper was funded by the Ontario Workplace Safety and Insurance Board. 


\section{NOTES}

1. Opinions diverge on the pros and cons of using professional actors vs. having injured workers enact their own experiences. In Easy Money, the use of professionals contributed significantly to the effectiveness of the play from the injured workers' perspective by enhancing the perceived social significance of their private experiences.

\section{REFERENCES}

Eakin, J. 2005. “The Discourse of Abuse in Return-to-Work: A Hidden Epidemic of Suffering”, Chapter 9, in Peterson, C. and Mayhew, C. (Eds.), Occupational Health and Safety: International Influences and the new Epidemics (Chapter 9). New York, NY: Baywood Publishing.

Eakin, J., E. MacEachen and J. Clarke. 2003. “'Playing It Smart' with Return to Work: Small Workplace Experience under Ontario's Policy of Self-Reliance and Early Return.” Policy and Practice in Health and Safety 1(2): 19-41.

Gray, R. and C. Sinding. 2002. Standing Ovation: Performing Social Science Research about Cancer. Walnut Creek, CA: AltaMira Press.

McCall, M. 2000."Performance Ethnography: A Brief History and Some Advice." In N.K. Denzin and Y.S. Lincoln, eds., Handbook of Qualitative Research (2nd ed.) (pp. 421-33). Thousand Oaks, CA: Sage Publications.

\section{Call to Authors}

Linkage and Exchange provides a forum for knowledge translation (KT) case studies. Submissions should include an abstract of no more than 100 words, a brief statement of background and context, a description of the $\mathrm{KT}$ initiative, a presentation of results (including challenges that arose and how they were addressed) and a discussion of lessons learned, highlighting those that are potentially transferable to other topics and settings. Manuscripts should be a maximum of 2,000 words, excluding the abstract and references.

\section{Appel aux auteurs}

«Liens et échanges » fournit un forum pour des études de cas en application des connaissances $(\mathrm{AC})$. Les articles soumis doivent comporter un résumé d'au plus 100 mots, une brève mise en contexte, une description de l'initiative d'AC, une présentation des résultats (y compris les défis qui se sont présentés et comment ils ont été relevés), ainsi qu'une discussion des leçons apprises, surtout celles qui sont potentiellement transférables à d'autres sujets et à d'autres cadres. Les manuscrits doivent être d'au plus 2000 mots, excluant le résumé et les références.

For more information contact Rebecca Hart, Managing Editor, at rhart@longwoods.com. 